\title{
Summary account of the Lower Ordovician (Arenig) graptolite biostratigraphy of the Cow Head Group, western Newfoundland
}

\author{
S. HENRY WILLIAMS AND ROBERT K. STEVENS
}

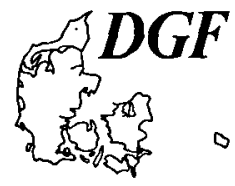

Williams, S. H. and Stevens, R. K.: Summary account of the Lower Ordovician (Arenig) graptolite bio-
stratigraphy of the Cow Head Group, western Newfoundland. Bull. geol. Soc. Denmark, vol. 35, pp. 259-
270 , Copenhagen, July 1st, 1987.

0

\begin{abstract}
The Cow Head Group is an allochthonous sequence of Middle Cambrian to late Arenig sedimentary breccias, limestones and shales deposited in a deep lower slope environment close to a continental margin. Imbricate thrusting has resulted in repeated exposure of laterally equivalent "proximal" to "distal" facies which may be correlated using graptolitic control in the interbeds. "Proximal" sections are characterised by massive, coarse breccias with interbedded limestones and green/dark grey shales. More distal exposures have fewer and thinner breccias and limestones, while the green/grey shales are replaced progressively by red, non-graptolitic ones.

Although the succession is by no mean unbroken or complete, it furnishes one of the best and most continuously graptolitic sections through the Arenig. A new zonal scheme is erected for the Cow Head Group, which could prove suitable as a new North American standard. Furthermore, several limestones and siliceous shales have yielded exquisitely preserved isolated material, permitting integration of fine growth detail with complete flattened specimens.

With the exception of the uppermost Arenig $U$. austrodentatus Zone, Arenig graptoloids possess a prosicular origin for thl ${ }^{1}$. The earliest graptoloids with a metasicular origin for the first theca appear in this zone, including Undulograptus, Cryptograptus and Paraglossograptus. This interval, equivalent to Dal of the Australasian scheme, therefore represents a hitherto unrecorded major evolutionary step in graptolite evolution.
\end{abstract}

S. Henry Williams and Robert K. Stevens. Dept. of Earth Sciences, Memorial University of Newfoundland, St. John's, Nfld, Canada AlB 3X5, August 29th, 1986.

The Cow Head Group is composed of a series of coarse sedimentary breccias or conglomerates with interbedded limestones and shales, together with subordinate silts, cherts and dolostones. It ranges in age from late Middle Cambrian to late Arenig. The base is nowhere seen, but the unit is overlain by green sandstones of the Lower Head Formation (James and Stevens 1986), considered to be of turbidite origin (Stevens 1970).

Much discussion on the Cow Head Group has been centred around the origin of the breccias. Logan (1863) considered them to be part of a simply bedded sedimentary sequence. Dawson (1883) and Walcott (1894) inferred that they resulted from the action of sea ice on a shallow water carbonate sequence. Schuchert and Dunbar (1934) offered an entirely different view; they considered that some breccias were tectonic, while others were derived from the erosion of advancing submarine thrust sheets. Barrington Brown (1938) compared them to sedimentary slide breccias, while Johnson (1941) regarded the sequence as a broken but relatively complete and simple one. Oxley (1953) returned to the ideas of Schuchert and Dunbar, concluding the breccias to be "thrust breccias" and that the intervening limestone-shale beds were large blocks within these units. Kindle and Whittington (1958) finally recognised the Cow Head Group as having a regular sedimentary origin with an age from Middle Cambrian to Middle Ordovician. They numbered the beds from 1 to 14 , an informal system still used with the addition of a Bed 15 not exposed at Cow Head. The breccias are now thought to have been deposited through a series of debris flows, bringing blocks of shallow water carbonates into a deep water setting (James and Stevens 1986). They also eroded the underlying deep water sediments to a greater or lesser extent which now form the bulk of incorporated clasts, especially in the more distal exposures.

The Cow Head Group is considered allochtho- 
nous; it was probably transported at least $150 \mathrm{~km}$ from the north-east during the Taconic Orogeny (Rodgers and Neale 1963; Stevens 1970 - see James and Stevens 1986 for discussion). It now rests in proximity to stratigraphically equivalent autochthonous shallow water carbonates of the St. George and Table Head Groups. A second allochthonous unit, the Curling Group, is also present; it is considered more distal in origin and is mostly older than the Cow Head Group. The Lower Paleozoic sediment pile is overlain through thrust contact by Grenville gneiss and granite which forms the core of the Long Range Mountains (fig. 1).

The imbricate nature of the Cow Head Group and overlying Lower Head Formation exposures is of uncertain genesis. The sequence has never been buried deeply; this is demonstrated by undeformed macrofossils and low conodont colour alteration index of 2.5, making emplacement as a subophiolitic accretionary prism extremely unlikely. The structure does, however, allow an insight into the transition of a sedimentary environment from lower continental slope to toe of slope in an approximately west-east direction. Most "proximal" sections, such as Lower Head and Cow Head, are characterised by massive polymict breccias, abundant limestone-shale rhythmites and green/grey/black shale intervals. Distally the breccias decrease in thickness, number, clast size and variety of composition, while limestones and green/grey shales become scarcer and red shale predominates. This suggests that the oxygen minimum existed at some distance upslope, oxygen content increasing with depth. Correlation of the sections is made possible through graptolites present in the interbeds, and conodonts in limestones. Coeval shallow water shelly faunas occur in limestone clasts in the breccias, permitting integration of several biostratigraphical schemes (Kindle and Whittington 1958). Previous faunal studies have concentrated on the trilobites (e.g. Whittington 1963) and conodonts (e.g. Fåhraeus and Nowlan 1978). Ongoing research is centred on the conodonts (C. $R$. Barnes et al.) and graptolites (S. H. Williams, R. K. Stevens and B.-D. Erdtmann) from the Upper Cambrian and Ordovician.

\section{History of graptolite research}

Graptolites were first collected from the Cow Head Group, together with other fossils, by Richardson in the 1860's during early work by the Geological Survey of Canada, which were subsequently incorporated by Billings in Logan's "Geology of Canada" (1863). These specimens were among collections of Canadian material sent to Lapworth at Birmingham University for identification. Although they were studied the results do not appear to have been used or published. Schuchert and Dunbar (1934) made extensive faunal collections, but the first critical conclusions on biostratigraphy were based on graptolites collected by Johnson's field assistant Kindle. Ruedemann studied these in detail and incorporated the results in his "Graptolites of North America" published in 1947. He included extensive faunal lists, together with a few illustrations and new taxa based on the Cow Head material.

Kindle and Whittington (1958) were the first to give a critical stratigraphical account of the graptolite faunas. They compared the succession with the Australian standard and proposed a correlation between the graptolitic and North American shelly zonal schemes. Our work has involved extensive recollecting through the Arenig at a limited number of localities (fig. 1). This has permitted critical taxonomic revision, incorporating isolated, three-dimensional material, and the erection of a new zonal scheme with eight divisions through the Arenig.

\section{Completeness of the Arenig graptolite succession}

The Cow Head Group contains possibly the most complete and continuously graptolitic Arenig sequence in the world. Both faunal and sedimentary breaks occur, but these are clearly recognisable and well understood due to the number of sections studied. The most obvious erosion occurs at the bases of several major breccia horizons, notably the bases of Beds 10 and 12 at Cow Head and Bed 14 at Lower Head, where the cross-cutting relationship with underlying limestone-shale lithologies is unambiguous. Less noticeable, but equally important breaks occur throughout the interbeds. Some erosive intervals 
are indicated by channelling and phosphorite conglomerate horizons, while others may be inferred through absence of lithological or biostratigraphical intervals present at neighbouring localities. Thus the thickness of Bed 11 on the Ledge section at Cow Head is only one half to two thirds the total thickness of that at Jim's Cove only a few hundred metres along strike. Likewise beds representing the $T$. akzharensis Zone thin from about $5 \mathrm{~m}$ at the eastern part of the Cow Head peninsula to $0.5 \mathrm{~m}$ at the Ledge section, a present distance of little more than one kilometre. Successions in the down slope sections are probably more complete, but are characterised by larger proportions of red and green non-graptolitic shales.

The picture is complicated further by ubiquitous but subtle tectonic deformation. Much cross-faulting and parasitic folding is obvious, but a large number of low angle faults substantially alter the interbed successions and are visible only through detailed critical investigation. A progressive change from early low angle through higher angle faulting is apparent, culminating in late-stage, extensional block faulting. Much of the early step faulting which almost parallels bedding may have been syn-sedimentary, related to downslope movement of the sedimentary pile. This is consistent with the faulting's subtle and commonly masked relationship within less competent shale lithologies. It would also explain why this style of deformation is most common in the more proximal localities on Cow Head where the slope was probablysteeper.

Despite these complexities, the Cow Head Group apparently represents one of the world's most complete and thoroughly documented graptolitic successions through the Tremadoc and Arenig. Although graptolite occurrence is not continuous, all zonal intervals are represented by several horizons and the large number of exposed sections permits a more-or-less complete composite picture to be compiled. Additionally, some localities, in particular St. Paul's Inlet and to a lesser extent Western Brook Pond, yield limestones with three-dimensional graptolites which have been isolated successfully using acetic acid. Siliceous shales at both these localities and at Martin Point (North) have also been digested using hydrofluoric acid, revealing flattened, but equisitely preserved isolated material that has responded well to bleaching treatment to reveal growth fusellae. The combination of abundant flattened or partially flattened non-isolated graptolites with flattened bleached specimens and three-dimensional unbleached ones has allowed an unique integration of overall form, growth structure and fine fusellar detail from the one stratigraphic unit.

Many lithologies are somewhat atypical for graptolite preservation; the most fossiliferous lithology is a dark grey, slightly brown, silty shale, which is commonly interbedded with either dark limestone or pale green shale. Black, very finegrained paper shales with a somewhat "soapy" texture occasionally yield fragments but are mostly non-graptolitic. They perhaps represent very slow background deposition which was insufficiently rapid to bury the organic skeletons prior to decomposition. Other graptolitic lithologies include parted limestones, where the rhabdosomes occur mostly on the limestone-shale boundaries, and in grainstones, where they are normally preserved too poorly to be of much taxonomic value. The three-dimensional graptolites from St. Paul's and Western Brook Pond occur in pale brown, concretionary limestones. These represent early diagenetic precipitation of carbonate along black graptolitic shale bands prior to compaction. Many such nodular bands clearly grade laterally into graptolitic shale yielding flattened specimens. It is unclear why such horizons should be restricted to these two localities when similar limestones abound at other sections, particularly Cow Head.

\section{Arenig biostratigraphy of the Cow Head Group}

The following summary is preliminary, while sections shown (fig. 1) are composite and schematic. Fully detailed measured sections and accurate range charts with zonal definitions, together with extensive taxonomic revision, will be given by Williams and Stevens (in press). A selection of representative taxa is illustrated in figs. $2-4$. The new zonal scheme is based partially on the Australasian standard (see VandenBerg 1981), especially for the isograptid intervals, but is defined on the Cow Head sections. It is essentially, therefore, a local biostratigraphic scheme, but is more 


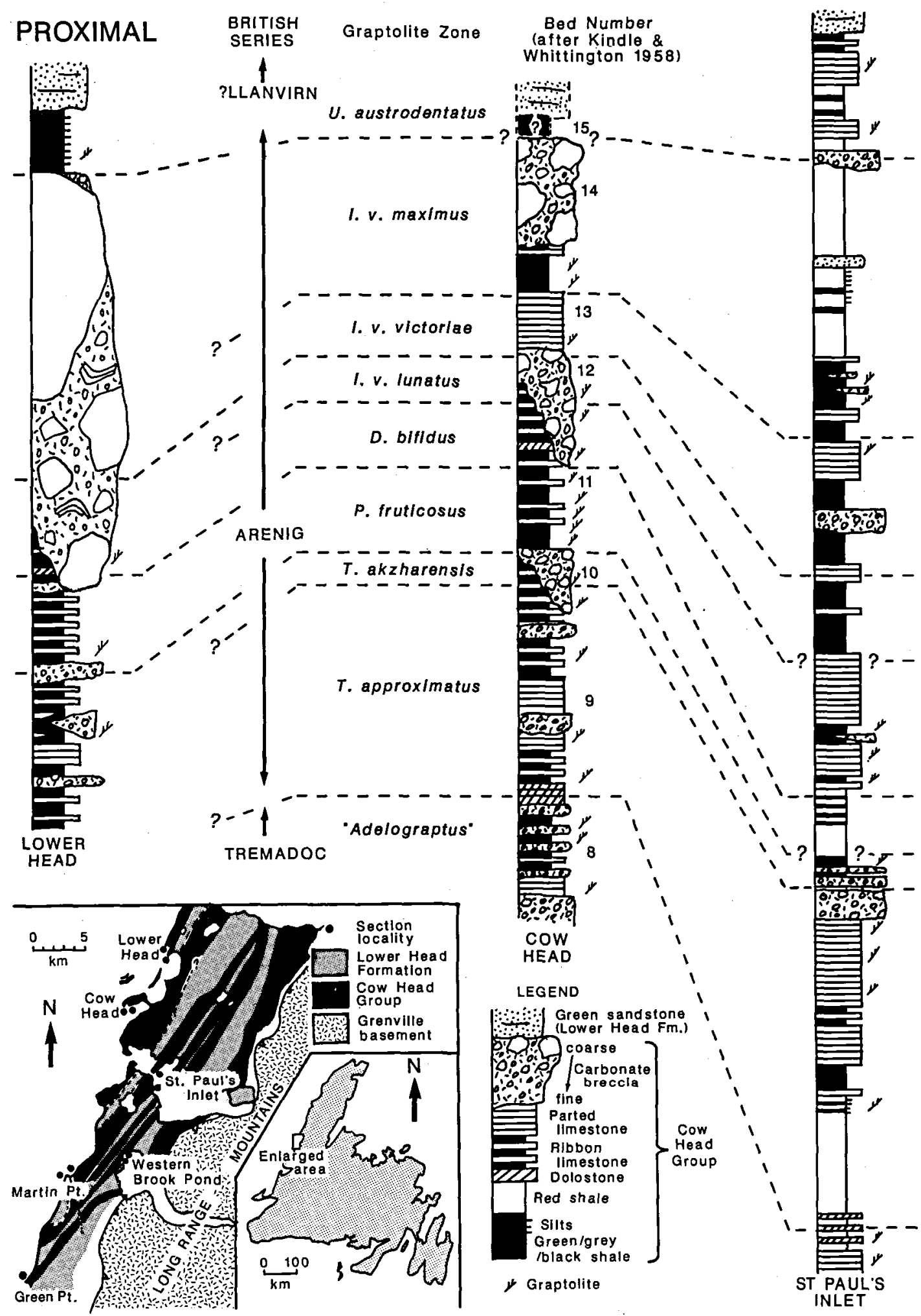




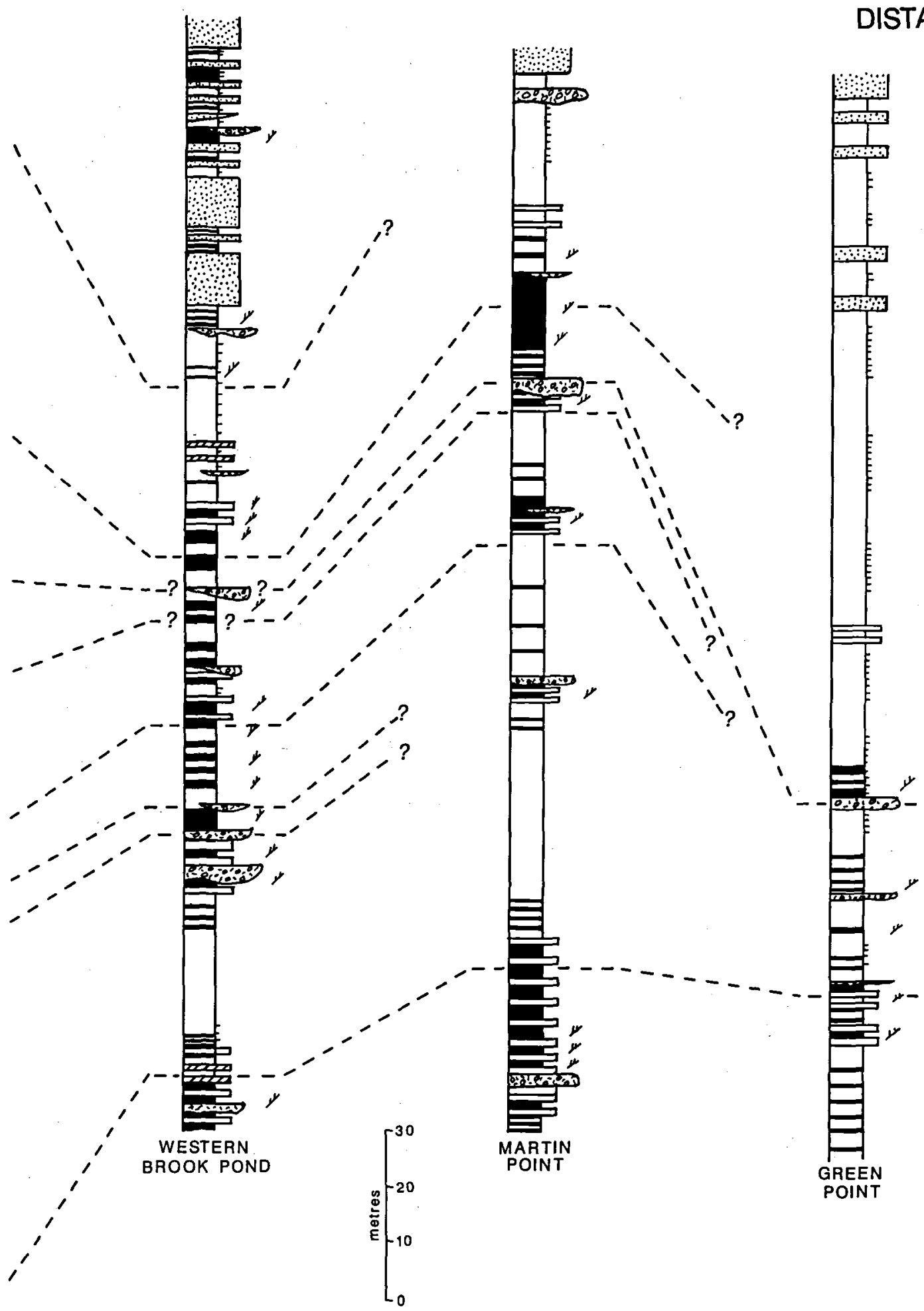

Fig. 1. Schematic, composite sections through the Cow Head Group. Lithological columns adapted from James and Stevens (1986). Correlation lines are based solely on graptolitic biostratigraphical data. 

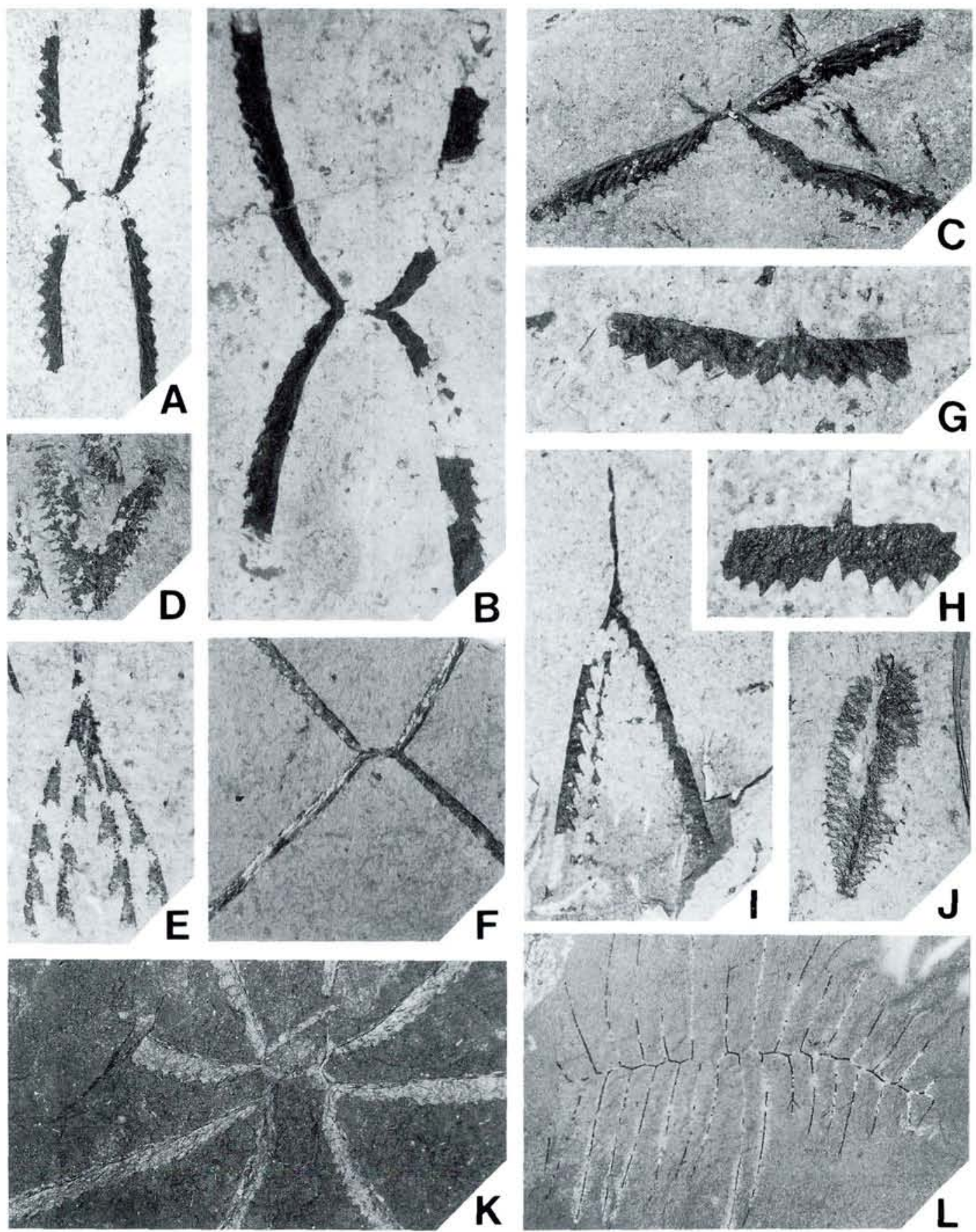

Fig. 2. Representative graptolite taxa of the Cow Head Group with biostratigraphical ranges.

A. Tetragraptus approximatus Nicholson $(\times 2.5)$. GSC 79725. T. approximatus-T, akzharensis zones. B. Tetragraptus acclinans Keble (×2.5). GSC 79885, T. approximatus-T. akzharensis zones. C. Tetragraptus serra (Brongniart) $(\times 2.5)$. GSC 79687. T. akzharensis-1. v. maximus zones. D. Tetragraptus phyllograptoides Strandmark $(\times 2.5)$. GSC 81473, T. akzharensis Zone, E. Pendeograptus cf. pendens (Elles) $(\times 5)$. GSC 79672. T. approximatus-P. fruticosus zones. F. Tetragraptus akzharensis Tjaz $(\times 2.5)$. GSC 82067 . T. akzharensis Zone. G. Didymograptus (Expansograptus) constrictus (J. Hall) $(\times 5)$. GSC 79677. T. akzharensis Zone. H. Didymograptus (Expansograptus) latus T. S. Hall $(\times 5)$. GSC 79727. T. approximatus-T. akzharensis zones. I. Pendeograptus fruticosus (J. Hall) $(\times 2.5)$. GSC 79626. P. fruticosus-D. bifidus zones. J. Pseudophyllograptus sp. nov. ( $\times 2.5)$. GSC 79897. T. akzharensis Zone. K. Dichograptus octobrachiatus (J. Hall) $(\times 2.5)$. GSC 79655a (latex peel). P. fruticosus Zone. L. Sigmagraptus praecursor Ruedemann $(\times 1)$. GSC 79582. P. fruticosus-I. v. lunatus zones. 

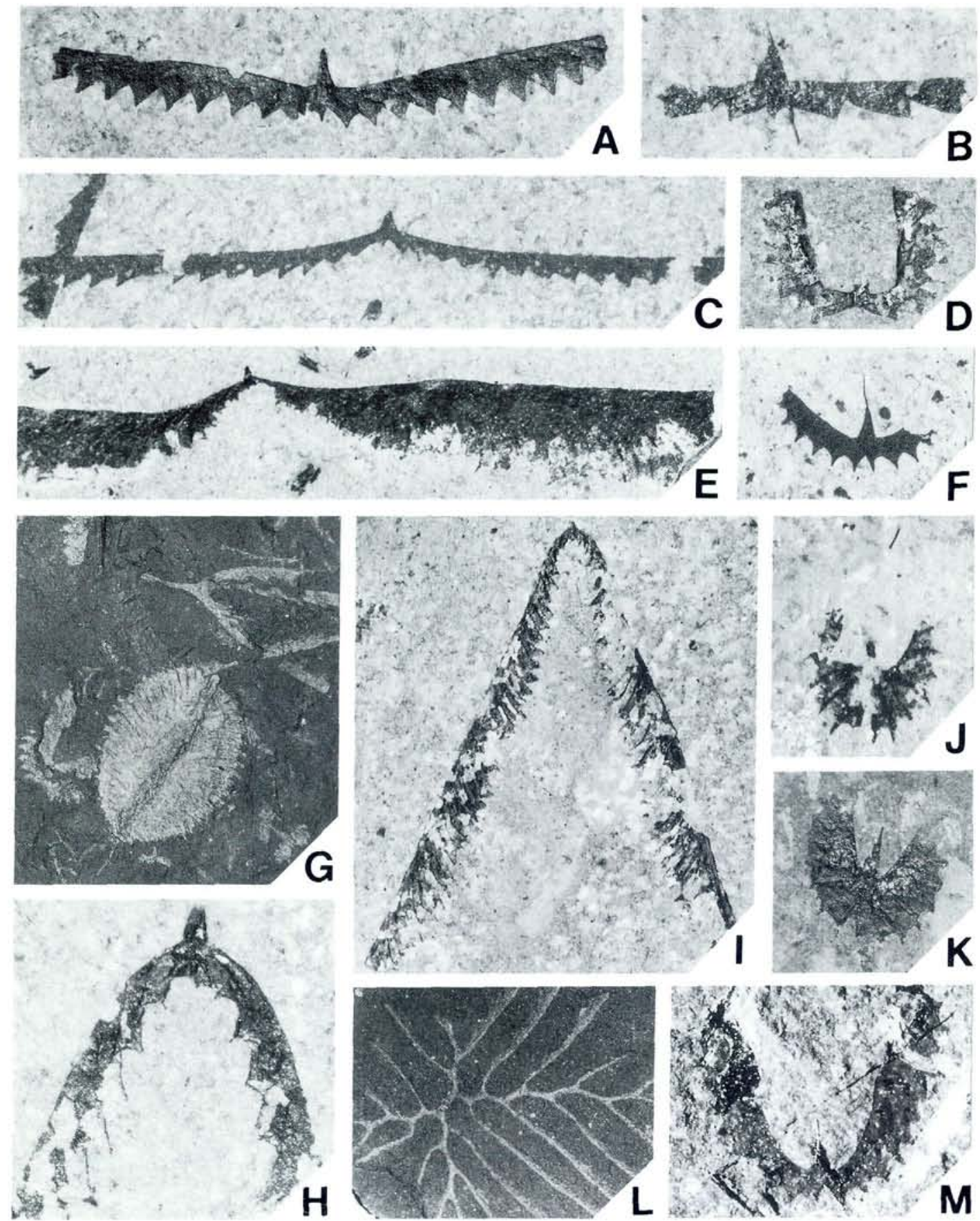

Fig. 3. Representative graptolite taxa of the Cow Head Group with biostratigraphical ranges

A. Didymograptus (Expansograptus) similis (J. Hall) $(\times 5)$. GSC 79762. T. akzharensis-D. bifidus zones. B. Xiphograptus formosus svalbardensis (Archer and Fortev) $(\times 10)$. GSC 81705 . P. fruticosus-1. v. maximus zones. C. Didymograptus (Expansograptus) nitidus (J. Hall) $(\times 5)$. GSC 79608. P. fruticosus zone. D. Tetragraptus bigsbyi (J. Hall) $(\times 5)$. GSC 79605. P. fruticosus-I. v. lunatus zones, E. Didymograptus (Expansograptus) pennatulus (J. Hall) $(\times 2.5)$ GSC 79639. P. fruticosus Zone. F. Didymograptus cf. hemicyclus Harris ( $\times 5)$. GSC 81514. D. bifidus-I. v. maximus zones. G. Phyllograptus typus J. Hall $(\times 2.5)$ GSC 79552 a (latex peel). P. fruticosus-I. v. victoriae zones. H. I. Didymograptus (Didymograptellus) bifidus (J. Hall), D. bifidus Zone. H. GSC 81699 ( $\times 10)$ ) 1. GSC 81752 $(\times 2.5)$. J. Isograptus ef. primulus Harris $(\times 10)$. GSC 81586 . D. bifidus Zone. K. Isograptus victoriae victoriae Harris $(\times 5)$. GSC 81731. I. v. victoriae Zone. L. Goniograptus thureaui (M'Coy). (×2.5). GSC 79628 (latex peel). P. fruticosus-I. v. maximus zones. M. Isograptus victoriae lunatus Harris $(\times 5)$. GSC 81719 . I. v, lunatus Zone. 

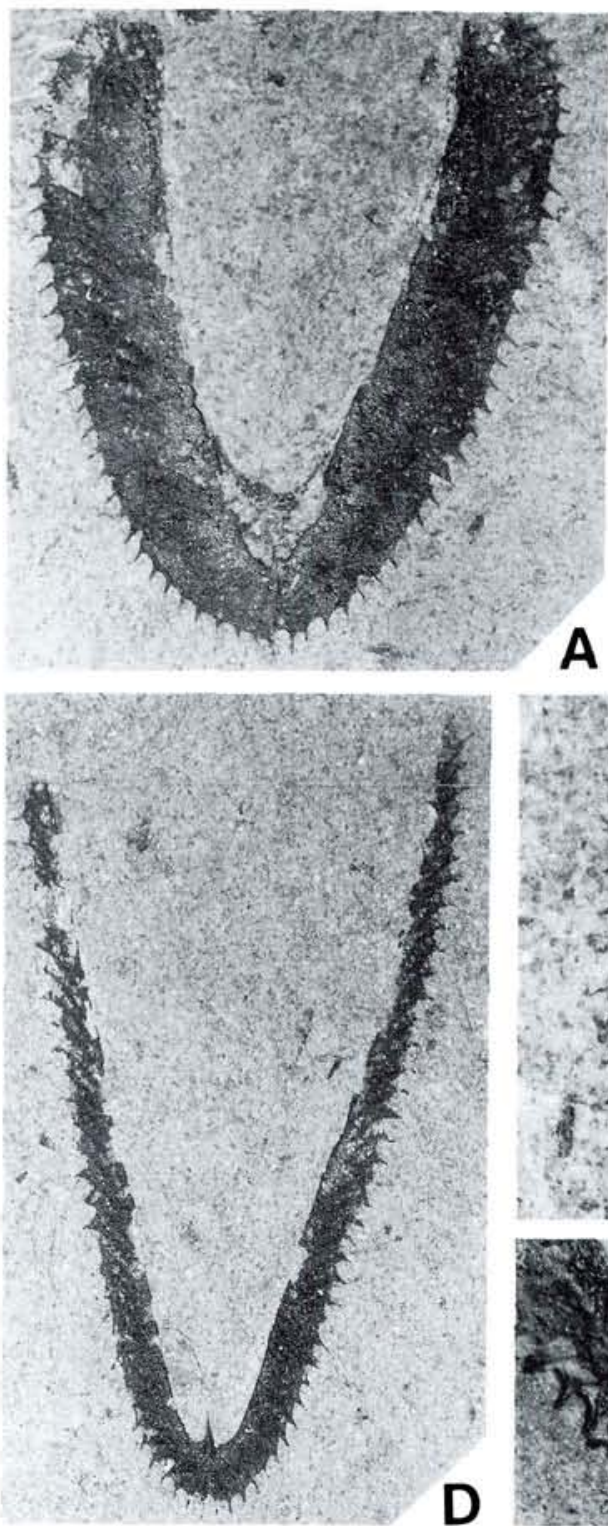
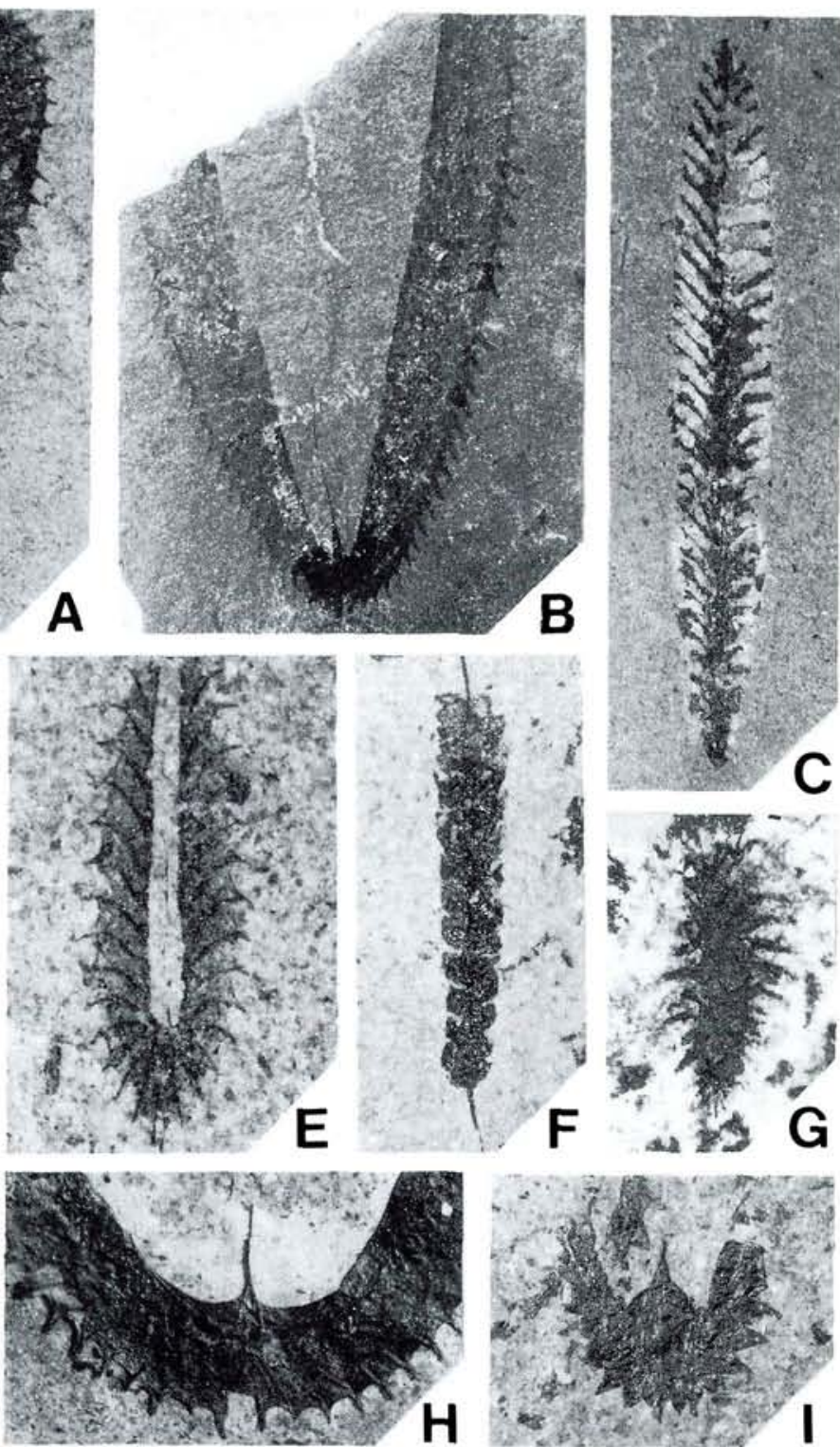

Fig. 4. Representative graptolite taxa from the Cow Head Group with biostratigraphical ranges.

A. Isograptus victoriae maximus Harris $(\times 2.5)$. GSC 81429. I. v. maximus Zone. B. Isograptus victoriae divergens Harris $(\times 2.5)$. GSC 81458. I. v, maximus-U. austrodentatus zones. C. Pseudotrigonograptus ensiformis (J. Hall) $(\times 2.5)$. GSC 81436. L. v. lunatus-U. austrodentatus zones. D. Isograptus caduceus australis Cooper $(\times 2.5)$. GSC 81444 . I. v. maximus $-U$. austrodentatus zones. E. Isograptus cf. forcipiformis Ruedemann ( $\times 5$ ). GSC 81624b, I. v. maximus Zone. F. Undulograptus austrodentatus austrodentatus Harris and Keble) ( $\times 5$ ). GSC 81566. U. austrodentatus Zone. G. Paraglossograptus tentaculatus (J. Hall) $(\times 5)$. GSC 81552. U. austrodentatus Zone. H. Isograptus victoriae maximus Harris ( $\times 5)$. GSC 81532 . I. v, maximus Zone. 1. Pseudisograptus dumosus Harris $(\times 5)$. GSC 81630. I. 1. maximus-U. austrodentatus zones.

likely to be relevant to other Canadian graptolitic units than the "borrowed" sequence given by Barnes et al. (1981). The Cow Head zonation therefore has great potential as a new Canadian, and possibly North American, standard. The
Arenig is divided into eight graptolite zones; latest geochronological estimates for this interval suggest an order of 15-20 million years (Gale et al. 1980; McKerrow in Kokellar et al. 1984, p. 247). The average duration of $2-2.5$ million years 
per graptolite zone falls short of the estimated one million years or less for the late Ordovician and Silurian (Rickards 1975), but this is far more precise than provided by either shelly macrofossils or conodonts and more reliably correlated. Because of the similarity with the Australasian graptolite zonal scheme, accurate correlation is achieved readily. Comparison with zonal successions elsewhere is more tentative, with the partial exception of Spitsbergen (Cooper and Fortey 1982), and requires fuller discussion than is possible within the present paper; this will be included by Williams and Stevens (in press).

We follow the standard practise adopted by graptolite workers in correlating the latest pregraptoloid burst of dendroids with the top Tremadoc Series, although such an assumption may apparently not be proved in the standard British sections. The topmost Tremadoc is characterised by a diverse dendroid fauna, with possibly a few true graptoloid elements. This is here provisionally referred to an "Adelograptus Zone", corresponding to the Adelograptus victoriae Zone of Australasia (Lancefieldian Stage 2). Following this is a non-graptolitic interval in all sections; at the more proximal locality of Cow Head this level is represented by a ca. $3 \mathrm{~m}$ bed of thinly interbedded dolomites and very pale green shales before the onset of darker grey, graptolitic limestones and shales yielding a Tetragraptus approximatus Zone fauna. Elsewhere this dolomitic unit is overlain by red, unfossiliferous mudstone reaching anywhere up to $50 \mathrm{~m}$ thick before the first $T$. approximatus Zone faunas are encountered. It is here assumed that the $T$. approximatus Zone is equivalent to the earliest Arenig (i.e. Lancefieldian 3 of Australasia); at Cow Head and St. Paul's Inlet it yields T. approximatus (Nicholson) and small Pendeograptus cf. pendens (Elles), together with Clonograptus flexilis (J. Hall). This assemblage remains constant throughout much of the zone; towards the upper part the earliest Didymograptus, D. (Expansograptus) latus T. S. Hall appears at St. Paul's Inlet and Western Brook Pond, although it has not been recorded from Cow Head. At the latter locality the later $T$. approximatus Zone yields Tetragraptus acclinans Keble and larger, more robust specimens of $P$. cf. pendens reminiscent of Pendeograptus fruticosus (J. Hall). These however have straighter and more sharply divergent stipes than seen in the typically "droopy" pendent form of $P$. fruticosus; it is uncertain whether these early examples consistently possess four stipes as recorded in the Australasian sequence (Thomas 1960; VandenBerg 1981). The uppermost portion of the $T$. approximatus Zone at Cow Head is characterised by common "Rhabdinopora" - like dendroids in rather pale ribbon limestones. This is considered to be an environmentally, rather than biostratigraphically controlled assemblage.

The first major increase in faunal diversity occurs at the top of Bed 9 at Cow Head, with the first occurrence of Pseudophyllograptus (probably a new species), D. (Expansograptus) constrictus (J. Hall), Tetragraptus serra (Brongniart) and Tetragraptus akzharensis Tzaj, together with a rich nematophorous and rooted dendroid assemblage. The zone index fossil $T$. akzharensis was described from the T. approximatus Zone of Kazakhstan, U.S.S.R. by Tzaj (1974). The Cow Head material of this species is, however, far more abundant and complete. The T. akzharensis Zone varies from $0.5 \mathrm{~m}$ thick at the Ledge section of Cow Head to ca. $5 \mathrm{~m}$ below the Cow Head cemetery some $1 \mathrm{~km}$ east along strike. At the intervening locality of Jim's Cove the interval is not represented at all. A similar fauna occurs above the thick breccia referred to Bed 10 at St. Paul's Inlet; the zone is also represented at Western Brook Pond and possibly Martin Point. At St. Paul's the assemblage additionally includes a new subspecies of $T$. approximatus and Tetragraptus phyllograptoides Strandmark, while at Western Brook Pond rare D. (Expansograptus) similis (J. Hall) and $D$. (E.) ensjoensis Monsen are present.

This biostratigraphic interval separating the typical $P$. fruticosus Zone from a $T$. approximatus assemblage is considered sufficiently distinct to define as a new zone. The T. akzharensis Zone probably corresponds at least in part to the Australian " 4 - branched fruticosus Zone" (i.e. Bendigonian 2), but is defined more accurately and is probably of greater potential for correlation.

The following Pendograptus fruticosus Zone has an extremely rich and diverse fauna; in addition to the zone index fossil the assemblage includes abundant Dichograptus octobrachiatus (J. Hall), Tetragraptus serra (Brongniart), Didymograptus (Expansograptus) nitidus (J. Hall), D. 
(E.) extensus (J. Hall), D. (E.) similis (J. Hall), D. (E.) ensjoensis Monsen, D. (E.) pennatulus (J. Hall), Phyllograptus typus J. Hall, Sigmagraptus praecursor Ruedemann, Goniograptus thureaui (M'Coy) and Holmograptus cf. leptograptoides (Monsen). D. (E.) pennatulus and the sigmagraptids appear to be restricted to the upper part of the zone. The assemblage is most diverse at Cow Head; indeed the $P$. fruticosus Zone is only found elsewhere at Lower Head and Western Brook Pond, the interval being represented by red, non-graptolitic shale at other localities. The $P$. fruticosus Zone of the Cow Head Group correlates with Bendigonian stages 3 and 4 of Australasian. The Newfoundland succession shows little, if any, transition from early $P$. fruticosus with four stipes to late ones with two, and we consider such a distinction unsuitable for biostratigraphic division.

The earliest pendent didymograptids are represented by a few minute, slender forms found together with $D$. (E.) pennatulus at the Jim's Cove section on Cow Head. Didymograptus (Didymograptellus) bifidus (J. Hall) itself occurs soon after in a sudden burst, associated with two and threestiped forms of $P$. fruticosus. This assemblage is present at Cow Head, St. Paul's Inlet, Western Brook Pond and Martin Point, and also characterises the type locality of $D$. (D.) bifidus at Levis, Quebec. It is therefore quite clear that the $D$. bifidus Zone directly follows that of $P$. fruticosus, removing the need for an intervening " $D$. protobifidus Zone" as adopted for Canada without comment by Barnes et al. (1981). The taxonomic complexities involving the type material of these taxa will be discussed fully by. Stevens and Williams (in press.). Here we merely point out that the holotype of $D$. protobifidus Elles from Outerside, northern England is probably late Arenig or early Llanvirn, and repeat that the equation of the British Llanvirn " $D$. bifidus" with the lower Arenig types from Levis by Berry $(1960 ; 1968)$ is mistaken (see Jaanusson 1960; Skevington 1963; Bergström and Cooper 1973; Riva in Fischer 1977). The D. bifidus Zone of the Cow Head Group correlates with the Chewtonian Stage $(D$. protobifidus and $T$. fruticosus, and $D$. protobifidus zones) of Australasia.

The fauna of the D. bifidus Zone is largely similar to that of the preceding $P$. fruticosus Zone; the major change is a decreasing abundance of $D$.
(Expansograptus) species and gradual replacement by Xiphograptus, which is present but rare in earlier levels. Both within this and later zonal intervals, most representatives of the genus may be assigned to $X$. formosus svalbardensis (Archer and Fortey) (see also Cooper and Fortey 1982). The earliest populations consist entirely of horizontal rhabdosomes, with an ever increasing proportion of slightly deflexed forms from the succeeding $I$. $v$. lunatus Zone upwards. $P$. fruticosus (both two and three-stiped forms) is relatively common in the lower part of the D. bifidus Zone, but disappears by the upper part. Sigmagraptids remain abundant, beautifully preserved examples having been isolated from limestones at St. Paul's Inlet and Western Brook Pond.

Rare specimens of Isograptus cf. primulus Harris occur at Cow Head in strata which we assign to the $D$. bifidus Zone, while at other localities " $D i$ dymograptus cf. hemicyclus Harris" of Cooper $(1973,1979)$ appears at an equivalent horizon. Although this interval might be separated as a discrete zone, insufficient fauna has been collected to justify such a step at the present time. The base of the $I$. v. lunatus Zone (equivalent to Castlemainian 1 of Australasia) is marked by the appearance of Isograptus victoriae lunatus Harris, which appears at the top of Bed 11 on the Cow Head peninsula. This zone also contains abundant $X i$ phograptus formosus svalbardensis (mostly horizontal forms) and Dichograptus solidus Harris and Thomas, which occurs only rarely in the preceding $D$. bifidus Zone. A rich $I$. v. lunatus Zone fauna is present in siliceous shales at Martin Point (North), below a massive breccia referred to Bed 12 by James and Stevens (1986). The graptolites are flattened, but respond well to isolation by hydrofluoric acid and bleaching with concentrated nitric acid and potassium chlorate. The assemblage includes abundant I. v. lunatus, Pseudotrigonograptus ensiformis (J. Hall), Xiphograptus formosus svalbardensis, Kinnegraptus kinnekullensis Skoglund and Didymograptus (s.l.) mendicus Keble and Harris. This last species is a peculiar pendent didymograptid with apparently folded thecal apertures and has an asymmetric, almost "artus - like" development which Cooper and Fortey (1982) considered characteristic of Llanvirn didymograptids.

The succeeding $I$. v. victoriae Zone includes abundant examples of the zone index fossil, Pseu- 
disograptus hastatus (Harris) and Pseudotrigonograptus ensiformis (J. Hall). It correlates with Castlemainian 2 of the Australasian scheme. The I. v. maximus Zone is well represented at almost all studied sections. We originally considered the large isograptid present to be $I$. $v$. maximodivergens Harris but R. A. Cooper (pers. comm.) states that most lie within his defined population of I. v. maximus Harris. The associated assemblage is second in abundance and diversity only to the $P$. fruticosus Zone. Besides the zone index fossil it includes Pseudisograptus hastatus (Harris), Pseudisograptus dumosus (Harris), "Isograptus cf. forcipiformis (Ruedemann)" (of Cooper 1973; 1979), Pseudotrigonograptus ensiformis (J. Hall), Tetragraptus serra (Brongniart), Xiphograptus sp. nov. $(=D . v$-deflexus Harris of Cooper 1979), $X$. formosus svalbardensis (Archer and Fortey), Goniograptus sp. and other sigmagraptids. The later part of the zone also contains Isograptus caduceus australis Cooper and early specimens of $I$. v. divergens Harris, while rare specimens of Pseudisograptus(?) tau (Harris) and P(?) aggestus (Harris) are present at St. Paul's Inlet and Western Brook Pond. Further work may allow the subdivision of the $I$. $v$. maximus Zone into two, based on presence or absence of these taxa. The lowest part of the $I$. $v$. maximus Zone is equivalent to Castlemainian 3 of the Australasian sequence. The distinctive zone index fossils characteristic of the following Yapeenian Stage are not, however, present in the Cow Head Group; we consider their absence due to geographic, environmental or preservational control rather than to a stratigraphical non-sequence. By comparison with the remaining faunal assemblage, the upper part of the I. v. maximus Zone is probably equivalent to Yapeenian 1, while the unfossiliferous portion of high Bed 14 may correlate with Yapeenian 2.

The latest Arenig Undulograptus austrodentatus Zone (equivalent to Darriwilian 1 of Australasia) is not exposed at Cow Head itself, but is well developed in strata underlying and within the basal green sandstones of the Lower Head Formation at Lower Head, St. Paul's and Western Brook Pond. The assemblage includes $U$. austrodentatus austrodentatus (Harris and Keble), U. austrodentatus cf. americanus (Bulman), Cryptograptus cf. antennarius (J. Hall), Paraglossograptus tentaculatus (J. Hall), Isograptus victoriae divergens Harris, $I$. caduceus australis Cooper, Pseudisograptus dumosus (Harris), Pseudotrigonograptus ensiformis (J. Hall), Xiphograptus formosus cf. formosus (Bulman) and Holmograptus sp. nov. Flattened examples of this fauna have been successfully isolated and bleached from siliceous shales at St. Paul's Inlet; although not particularly well preserved, they do permit observation of proximal development in this distinctive assemblage.

\section{Origin of thl ${ }^{1}$ and the Arenig-Llanvirn boundary}

During the present study, many Arenig graptolite taxa have been isolated successfully. Although three-dimensional specimens were unable to withstand bleaching without collapse, flattened material from siliceous shales reponded well to such treatment. This permitted observation of three-dimensional form both by reflected light and scanning electron microscopy and of fusellar structure in flattened specimens through transmitted light examination. Species isolated include Tetragraptus approximatus, T. bigsbyi, T. serra, Pendograptus cf. pendens, P. fruticosus, Didymograptus (Didymograptellus) bifidus, D.(Expansograptus) similis, Phyllograptus typus, $X i$ phograptus formosus svalbardensis, Isograptus victoriae lunatus, I. v. victoriae, Kinnegraptus kinnekullensis, Holmograptus cf. leptograptoides, Sigmagraptus praecursor, Undulograptus austrodentatus austrodentatus, $U$. austrodentatus americanus and Paraglossograptus tentaculatus.

One observation is clear; except for those from the uppermost Arenig U. austrodentatus Zone, all graptoloids in the Arenig have a prosicular origin for the first thecae (with the one possible exception of $H$. cf. leptograptoides). Only with the incoming of the austrodentatus fauna (Dal equivalent) do graptoloids such as Undulograptus, Cryptograptus and Paraglossograptus have a metasicular origin for thl $\mathrm{l}^{1}$. Further study on isolated material from equivalent successions elsewhere is now required in order to establish whether this event is cosmopolitan and synchronous with the appearance of the diplograptids. It would also be of value to find whether all genera (such as the isograptids and didymograptids) which survive the Arenig-Llanvirn transition evolve a metasicular origin for thl ${ }^{1}$, or whether they retain their prosicular origin. At present the Arenig-Llanvirn boundary has yet to be defined formally and cor- 
relation with the graptolite succession is unclear. Future definition is likely to be based on shelly faunas, but should graptolites be considered a viable alternative, the onset of metasicular origin for $\mathrm{thl}^{\mathrm{l}}$, together with the appearance of the Diplograptidae, might prove a suitably significant basis on which to define the boundary.

Acknowledgments. We are grateful to NSERC, NRC and Memorial University of Newfoundland for financial assistance.

\section{Dansk sammendrag}

Cow Head Group er en allochton sekvens omfattende mellem kambriske til sent arenig sedimentære breccier, kalksten og skifre, der er aflejrede på de dybere dele af kontinental-skrænten tæt ved en kontinent grænse. Blok-forkastninger har haft til resultat, at der findes gentagne blotninger af identiske niveauer, men sådan, at de blottede lag stammer fra både proximale og distale facies (dvs. aflejringer fra tæt ved sedimentkilden og fjernere derfra). De forskellige facies kan korreleres gennem deres indhold af graptolitter. De proximale aflejringer består af massive, grove breccier med mellemlejrede kalksten og grønne til mørkegrå skifre. De mere distale aflejringer viser færre og tyndere breccier og kalksten og de grønne til grå skifre bliver afløst af røde graptolit-fri skifre.

Selvom lagfølgen ikke er komplet, er den, på trods heraf, en af de bedste og mest komplette serier gennem arenig perioden. Der etableres en zonering af Cow Head Group, som kan vise sig at være brugbar som ny nordamerikansk standard. Der ud over har adskillige kalksten og kiesel-rige skifre givet usædvanligt velbevaret fossil materiale, der har tilladt studier af finere vakst-detaljer.

På nær i det aller- $ø$ verste arenig ( $U$. austrodentatus Zonen) besidder alle arenig graptoloider en prosicula oprindelse for thl $\mathbf{l}^{l}$. De første graptoloider med en metasiculæer oprindelse af den første theca fremkommer i denne zone og omfatter $U n d u$ lograpus, Cryptograptus og Paraglossograptus.

Dette interval, som er ekvivalent til Dal i den austral-asiske zonering, reprasenterer derfor et hidtil ubeskrevet trin i graptolit evolutionen.

\section{References}

Barnes, C. R., Norford, B. S. and Skevington, D. 1981: The Ordovician System in Canada. Correlation chart and explanatory notes. I.U.G.S. Publ 8 .

Barrington Brown, C. 1938: On a theory of gravitational sliding applied to the Tertiary of Ancon, Ecuador. Q. $\mathrm{Jl}$. geol. Soc. Lond. 94, 359-370.

Bergström, S. M. and Cooper, R. A. 1973: Didymograptus bifidus and the trans-Atlantic correlation of the Lower Ordovician. Lethaia 6, 1625-1660.

Berry, W. B. N. 1960: Graptolite faunas of the Marathon region, west Texas. Publs. Bur. econ. Geol., Univ. Texas 6005, 1-129.

Berry, W. B. N. 1968: British and North American Lower Ordovician correlation; reply. Bull. geol. Soc. Am, 79, 12651272.

Cooper, R. A. 1973: Taxonomy and evolution of Isograptus Moberg in Australasia. Palaeontology 16, 45-115.
Cooper, R. A. 1979: Ordovician geology and graptolite faunas of the Aorangi Mine area, north-west Nelson, New Zealand. Palaeont. Bull. N.Z. geol. Surv. 47, 1-127.

Cooper, R. A. and Fortey, R. A. 1982: The Ordovician graptolites of Spitsbergen. Bull Brit. Mus. nat. Hist. (Geol.) 36, 157-302.

Dawson, J. W. 1883: The Quebec Group. In Harrington, B. J.: The life of Sir W. E. Logan., 404-414. Montreal.

Fåhraeus, L. E. and Nowlan, G. S. 1978: Franconian (late Cambrian) to early Champlainian (middle Ordovician) conodonts from the Cow Head Group, western Newfoundland. Jl. Paleont. 52, 444-471.

Fischer, D. W. 1977: Correlation of the Hadrynian, Cambrian and Ordovician rocks in New York State. Univ. State New York, Map and Chart Series 25.

Gale, N. H., Beckinsdale, R. D. and Wadge, A. J. 1980: Discussion of a paper by McKerrow, Lambert and Chamberlain on the Ordovician, Silurian and Devonian time scale. Earth Plan. Sci. Lett. 51, 9-17.

Jaanusson, V. 1960: On the series of the Ordovician System. Rep. XXI Int. Geol. Congr. Pt. 7, 70-81.

Jackson, D. E. 1962: Graptolite zones of the Skiddaw Group in Cumberland, England. Jl. Paleont. 36, 300-313.

James, N. P. and Stevens, R. K. 1986: Stratigraphy of the Cow Head Group, western Newfoundland. Bull. Geol. Ass. Can. 366, 1-143.

Johnson, H. 1941: Paleozoic lowlands of northwestern Newfoundland. Trans. N.Y. Acad. Sci. ser. II 3, 141-145.

Kindle, C. H. and Whittington, H. B. 1958: Stratigraphy of the Cow Head region of western Newfoundland. Bull. geol. Soc. Am. 69, 315-342.

Kokelaar, B. P., Howells, M. F., Bevin, R. E., Roach, R. A. and Dunkley, P. N. 1984: The Ordovician marginal basin of Wales. Spec. Pap. geol. Soc, Lond. 16, 245-270.

Logan, W. E. 1863: Geology of Canada; Geological Survey of Canada, report of progress from its commencement to 1863 , $983 \mathrm{pp}$.

Oxley, P. 1953: Geology of Parsons Pont - St. Paul's area, west coast, Newfoundland. Rep. Nfld. geol. Surv. 5, 1-53.

Rickards, R. B. 1975: Palaeoecology of the Graptolithina, an extinct class of the phylum Hemichordata. Biol. Rev. 50 , 397-436.

Rodgers, J. and Neale, E. R. W. 1963: Possible "Taconic" klippen in western Newfoundland. Am. Jl. Sci. 261, 713-730.

Ruedemann, R. 1947: Graptolites of North America. Mem. geol. Soc. Am. 19, 1-652.

Schuchert, C. and Dunbar, C. O. 1934. Stratigraphy of western Newfoundland. Mem. geol. Soc. Am. 1, 1-123.

Skevington, D. 1963: A correlation of Ordovician graptolitebearing sequences. Geol. För. Stockh. Förh. 85, 298-319.

Stevens, R. K. 1970: Cambro-Ordovician flysch sedimentation and tectonics in west Newfoundland and their possible bearing on a proto-Atlantic Ocean. Spec. Pap. geol. Ass. Can. $7,165-177$

Thomas, D. E. 1960: The zonal distribution of Australian graptolites. Jl. Proc. Roy. Soc. New South Wales 94, 1-58.

Tzaj. D. T. 1974: Graptolites of the Lower Ordovician in Kazakhstan. Izd. Nauk. Moscow, 1-127.

VandenBerg, A. H. M. 1981: Victorian stages and graptolite zones. In Webby, B. D. (ed.). The Ordovician System in Australia, New Zealand and Antarctica. Correlation chart and explanatory notes. I.U.G.S. Publ. 6, 1-64.

Walcott, C. D. 1894: Paleozoic intra-formational conglomerates. Bull. geol. Soc. Am. 5, 191-198.

Whittington, H. B. 1963: Middle Ordovician trilobites from Lower Head, western Newfoundland. Bull. Mus, Comp. Zool. 129 (1), 1-118.

Williams, S. H. and Stevens, R. K. in press. Arenig graptolites of the Cow Head Group, western Newfoundland. Palaeontogr. Canad. 